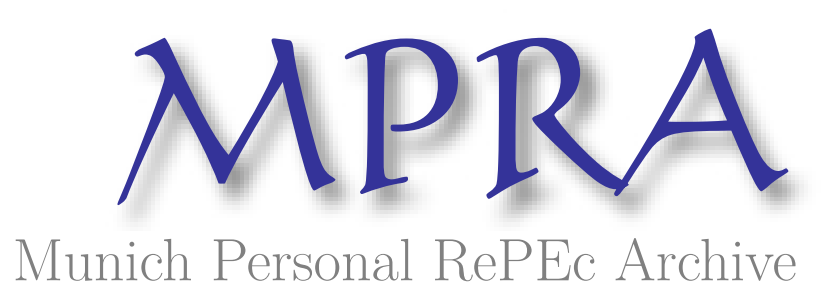

\title{
Privatization and growth: natural experiments of European economies in transition
}

Kant, Chander

29 November 2018

Online at https://mpra.ub.uni-muenchen.de/90302/

MPRA Paper No. 90302, posted 01 Dec 2018 14:18 UTC 


\title{
Privatization and growth: natural experiments \\ of European economies in transition
}

\section{Chander Kant ${ }^{\mathrm{a}, \mathrm{b}}$}

\begin{abstract}
We examine the relationship between privatization and growth of transition countries in Europe by using relative income and grouping them by ex-ante factors and by ex-post associations. For transition countries with comparable pre-1991 data also - Bulgaria, Hungary, Poland, and Romania or BHPR countries - privatization/regime change to market economy increased their annual catching-up-to-Germany from $0.90 \%$ to $1.50 \%$ but the increase was not due to higher TFP. It entirely occurred after they joined the EU, and is entirely due to higher contribution of human capital. Privatization did not impose short run costs on all countries while making CIS countries fell-behind very sharply. The greatly divergent post-transition growth both in the short and the long term cannot be explained by differing emphasis on external versus domestic liberalization. Catching-up of "new" ex-socialist SBCS countries (Slovenia, Baltic countries, the Czech republic and Slovakia) occurred only after they joined the EU. Human capital and TFP explain their growth while for Croatia and Serbia it is physical capital and TFP. Negative contribution of human capital is the sole reason underlying falling-behind of the CIS countries. Based on 1991-2013 catchingup/falling-behind, CIS countries have no prospect of ever equaling German income, pre-2004 EU Western-Europe will reach income equality with Germany in 70 years, BHPR countries in 72; SBCS countries in 104, and Croatia and Serbia in 193 years.
\end{abstract}

JEL Codes: O10, O47

Key Words: Command economy and market economy; "old" ex-socialist countries and "new" ex-socialist countries; accession to EU; factors behind differing post-socialist growth/catching-up; years for full convergence 
Acknowledgments: An earlier version of this paper was presented at the $35^{\text {th }}$ International Association for Research in Income and Wealth General Conference held August 20-25 in Copenhagen, Denmark. I am grateful to the participants, in particular to Andrew Clark, for helpful comments.

a Department of Economics, Seton Hall University, South Orange, NJ 07078, U.S.A.; E-mail address: chander.kant@ shu.edu; Telephone: 973-202-5964; Fax: 973-761-9217

${ }^{b}$ Kant Research, 1 Fielding Road, Short Hills, NJ 07078, U.S.A.; E-mail address: kant@kresearch.org; Telephone: 973-202-5964; Fax: none 


\section{Privatization and growth: natural experiments with European economies in transition}

\section{Introduction}

Economists have recognized that Solow (1956) and Swan (1956) model's physical capital, labor in efficiency units, and technology are "proximate" factors for growth that depend on “fundamentals" like institutions, colonial heritage, religious or legal traditions, culture. ${ }^{1}$ North's (1990) contribution emphasizing the role of institutions in growth is seminal. He defined them as "rules of the game... or... humanly devised constraints ... that structure incentives in human exchange, whether political, social, or economic." Rules of the game may either be codified in written laws, regulations, and instructions or they may be cultural traits, unwritten conventions and practices. Nunn (2014). If so, institutions overlap with cultural and legal traditions.

Jones and Romer (2010) highlight four state variables now at the center of growth theory - ideas, institutions, population, and human capital. They model three of them and specifically refrain from modeling institutions. Fuchs-Schundeln and Hassan (2016), defining institutions more precisely (following Acemoglu, 2009), separate them from social structure, and culture. Institutions are "the broad set of rules, regulations, laws, and policies that affect economic incentives and thus the incentives to invest in technology, physical capital, and human capital" while social structure is the network of friendships, family ties, and socioeconomic stratification (e.g., the class structure) that affects spread of information and ability to enforce contracts and culture essentially means civic capital that overcomes free rider problem. It is not feasible for one to conduct controlled experiments for any of the three at the level of countries. That leaves natural

\footnotetext{
${ }^{1}$ See, Rodrik (2003), Acemoglu et al. (2005). See, also Kant (2016) for additional references.
} 
experiments as the best means of drawing the causal relationships for all three.

As noted by Djankov and Murrell (2002), privatization of ownership and liberalization of markets in ex-socialist countries provide an excellent natural experiment to economists in view of their fast and all-encompassing introduction. Different theoretical models predict a positive relationship of privatization/liberalization with growth. In general equilibrium framework, Gylfason (1998) employing a two-sector full employment model and Hansen (1997) with an imperfect competition model, predict that privatization and market (instead of administered) prices either act like removing a price distortion through price reform/trade liberalization or enhances micro-economic efficiency through a broad distribution of ownership rights. These conclusions are supported by empirical studies by Berkowitz and DeJong (2003) for post-Soviet Russia; but not by Bennett et al. (2007) for 26 transition economies for 1990-2003, and Cieslik and Tarsalewska (2013) for 24 such economies for 1993-2006. On the speed of privatization, Bennett et al. (2007) report mass privatization led to greater post-privatization growth boost than gradual privatization while Gouret (2007) does not.

Estrin et al. (2009) using EBRD’s Transition Reports 1998-2007 data find privatization affected efficiency, profitability, revenues of firms mostly positively in Central Europe, while its effects on CIS states are statistically insignificant. Summarizing empirical macro studies, they find privatization has a positive effect on growth - especially when accompanied by complementary reforms - but whether mass privatization (often largely to insiders) has a stronger effect is not clear. The expected vast improvement from poor performance during the centrally planned period has not occurred partly due to sharp recession immediately following the launch of privatization. Using the 1995-2008 levels of Heritage Foundation's index of economic freedom 
(IEE) for most of the post-socialist countries, Piatek et. al (2013) find IEE, but not political freedom, Granger causes faster growth. ${ }^{2}$

Performing a meta-analysis of 60 empirical studies published from 1996-2013 of the first generation structural reforms in 26 transition economies, Babecky and Havranek (2014) find the reforms had substantial costs to growth in the short-run but more positive effects in the long-run, especially when they were focused on removing trade and capital account controls. Dell'Anno and Villa (2013) construct a broad index of institutional change for 1990-2008 from EBRD's transition (or reform) indicators for 27 Central and Eastern Europe and Commonwealth of Independent States (CIS) transition economies. They show that higher speed of reforms Granger causes growth (measured as an average for 27 countries) but not vice-versa. Eicher and Schreiber (2010) exploit the relatively large changes during transition, and construct a structural policy index by summing up EBRD's relevant liberalization indices from 1991-2001 for 26 transition countries. They find large short-term effects of structural policy on growth using a panel with fixed effects; or, alternatively, using "independence," (how politically free a country was in 1988) as instrument for economic institutions.

European economies in transition also provide setting for a second natural experiment. On May 1, 2004, the following transition economies joined the European Union: the Czech Republic, Estonia, Latvia, Lithuania, Hungary, Poland, Slovakia, and Slovenia. They were soon followed by Bulgaria and Romania (on January 1, 2007). Upon joining, they were required to follow EU standards, norms, regulations, and practices. Such a large number of countries adopting EU norms

\footnotetext{
${ }^{2}$ They find more than half of the CIS countries were not politically free, and had decreasing political rights over this period.
} 
at the same time also provides a natural setting to answer whether or not adopting EU norms and standards enhances growth or worsens it.

As far as I can tell, none of the studies cited above have examined growth effects of either EU accession or of privatization/regime change from a command to a market economy by grouping countries by either ex-ante factors or by ex-post associations. Longer-term (i.e., pre1991) comparable data, that is available for ex-socialist countries that that have been separate countries since the Second World War (Bulgaria, Hungary, Poland, and Romania), is eminently suitable for conducting a natural experiment for comparative study of growth effects of the two regimes: Command vs. Market. The other ex-socialist countries that emerged or re-emerged as independent new countries in 1991/1993, (and for which comparable pre1991 data is unavailable in any comprehensive way) can also be grouped by whether they had civil war as they became independent and separate countries or whether post-transition they formed into CIS or whether they aspired to join, and then joined, the EU instead. This permits us to conduct the second natural experiment: Whether adopting EU norms and standards has any effect on growth.

We use the longest comparable data that is available for transition economies to examine the open questions of the mechanism of privatization leading to economic success, if any; and their lessons for long term growth for developing countries. ${ }^{3}$ See, Estrin et al. (2009). These questions are empirically analyzed using data for countries in Central and Eastern Europe and the former Soviet Union preceding transition (if available) and following transition to a market-

\footnotetext{
${ }^{3}$ The splitting of Czechoslovakia into its two parts, the break-up of the former U.S.S.R. into its constituent republics, and the dissolution of the former Yugoslavia led to emergence or reemergence of many independent countries in 1991/1993.
} 
economy in 1991. We analyze the effects of privatization/regime from a command to a market economy for countries that have existed as separate countries since at least the Second World War in Section 2. The effects for countries that attained separate statehood for the first time in 1991/1993, are analyzed in Section 3. Section 4 concludes.

\section{2. "Old" ex-socialist countries under different regimes}

Two indices have been used to identify privatization/economic reforms in the literature on transition: Heritage Foundation's index of economic freedom and EBRD's transition (or reform) indicators. We prefer the latter since it is available from 1989 (as opposed to 1995 for the former). EBRD rates the following indicators on a scale of 1 (little progress or lowest level) to 4.33 (attainment of advanced industrial economy standards): Large-scale privatization, small-scale privatization, governance and enterprise restructuring, price liberalization, trade and foreign exchange system, and competition policy. For the "old" ex-socialist countries for which we have relevant data, called BHPR (Bulgaria, Hungary, Poland, and Romania) countries hereinafter, sum of these indicators rose very rapidly from the lowest level (6 to 8.7) in 1989. Although we do not have comparable data for the pre-1991 period, it is reasonable to assume these countries were at the same level of privatization/ liberalization (i.e., little) in the pre-1991 period as they were in 1989-1990.

We use the PWT data for income (and other variables) since it goes back the farthest. RGDP in its versions starting with 8.0 (the next generation, see, Feenstra et al. (2015)), permit real GDP comparisons across countries as well as over time; and we use its most recent version 9.0 (available at http://www.rug.nl/ggdc/productivity/pwt) that gives data to 2014. It is available for Romania since 1960 and for Bulgaria, Hungary, and Poland since 1970. For these countries it provides a natural experiment to analyze long-term performance under two different regimes: 
socialism and market economy. ${ }^{4}$

Figure 1 shows the three-year moving average (to smooth out short-run fluctuations) of PPP PCY index with base-years 1961 for Romania (and Germany) and 1971 for the other three countries. German income grew at an average of $2.5 \%$ between 1961 to 2013, was the least volatile, and exhibited no sharp change in or around 1990. Income ratios are frequently used in growth and transition studies. For example, Peron and Rey (2012) use time series analysis to examine the distribution of Indian Ocean Zone (IOZ) countries' incomes ratio to the IOZ average, and to the world mean income, Cuberes and Jerzmanowski (2009) examine growth reversals using real output per worker relative to the US, Fuchs-Schundeln (2008) use German Reunification as a natural experiment to study its effect on East-West Germany saving-ratio, income-ratio, and wealth ratio, and Jones and Olken (2008) find growth "miracles" and "failures, defined as growth relative to the US, are ubiquitous at ten-year periods. Svejnar (2002) compares Soviet bloc's growth to a corresponding group of market economies. Nevertheless, none of these studies use either a catch-up index or explanatory variables also as ratios.

Following Kant (2018), the catch-up index, that is based on income ratios, is defined as follows. Let $y_{\mathrm{J} 0}$ and $y_{\mathrm{BM}}$ represent Country J's per-capita RGDP for the base year and the bench mark country's per-capita RGDP for Country J's base year, and $R_{J_{0}}$ Country J's base per capita RGDP ratio. We assume the bench mark country is the richer country, for all time periods under

${ }^{4}$ Ver. 9.0 uses PPPs from the international comparison project (ICP) 2011 that removes some of the distortions of ICP 2005 used in PWT 8.0/8.1 (e.g., inclusion in ICP 2005 of many products typical in the consumption baskets of high-income countries that are high-priced luxury items in low-income countries). See, World Bank (2013, 2014) and Inklaar and Rao (2017). 
study. Then,

$$
R_{\mathrm{J} 0}=\left(y_{\mathrm{J} 0} / y_{\mathrm{BM} 0}\right)<1 .
$$

For each subsequent year, similar ratios of a country's annual per-capita RGDP to that of the bench mark country are computed. The catch-up index for Country $\mathrm{J}$ for year $t$ is the ratio of its per capita RGDP ratio for year $t$ to its base per capita RGDP ratio. Let $I_{\mathrm{Jt}}$ represent this index. Then,

$$
I_{\mathrm{Jt}}=\left(R_{\mathrm{Jt}} / R_{\mathrm{J} 0}\right)
$$

$I_{\mathrm{Jt}}$ is the index of income ratios. By converting all income ratios to the same base, the catch-up index helps us identify the breaks/turning points, and compare/combine different countries' experience. It is depicted for the four countries with respect to Germany for all available years in Figure 2. ${ }^{5}$ Its increase shows relative convergence (that is not sufficient for absolute convergence, i.e., for income gap to decrease), while its decrease shows both relative and absolute divergence (since, relative divergence is sufficient for absolute divergence). All BHPR countries exhibit both catching-up (relative convergence, RC) and falling back (relative divergence, RD). ${ }^{6}$

${ }^{5} \mathrm{We}$ use Germany as the anchor country since post-transition convergence of East European and CIS countries is often examined to it.

${ }^{6}$ Although Romania's index dominates Figure 2, it experiences falling behind from 1985 to 1992 and recovers its 1985 relative income only in 2006. Similarly, Bulgaria falls behind from its peak relative income in 1988 to a level below the 1971 level by 1998 and has still not re-attained the 1988 level. That is, it fails to catch-up for 25 years. Romania, and Bulgaria fail to catch-up for 21 years (1985-2006), and 25 years (1988-2013), respectively. Similarly, Poland shows no catching-up for 24 years (1971- 1995) and Hungary for 20 years (1983-2013). Catching-up of none of these countries is consistent and steady. 
Nevertheless, 1991 (or, just around 1991) marks a break-point/change in the previous trend (confirmed by cusum-of-squares test) for all four countries: Bulgaria from RC to RD, and Poland from no RC/RD to RC, and the other two countries from RD to no RC/RD for Romania and RC for Hungary. Thus, start of the privatization and market economy period in 1990/1991 marks the end of absolute income divergence for three out of four Eastern Europe ex-socialist countries for which data are available for the earlier period also.

Table 1 computes the average (geometric mean) catching-up rate for the BHPR countries separately for the two periods. ${ }^{7}$ The catching-up rate for the post-1991 period is more than onehalf point higher. The catching-up growth in the post-socialist period is higher and (as seen in Figure 2), the falling behind is less frequent. Nevertheless, the evidence of BHPR countries does not support the conclusion of Estrin et al. (2009) that centrally planned economies had poor economic performance in the pre-transition and were just waiting for privatization and market economy to burst into rapid growth. Eicher and Schreiber (2010), using a panel for 1991-2001 of 26 ex-socialist countries, find a mere 10\% change in quality of structural policies (measured by EBRD's TIs) raises annual growth by $2.7 \%$. We find the whole-scale adoption of privatization and structural change from command to market economy by BHPR countries increased growth rate by only 0.5 points.

${ }^{7}$ We prefer geometric mean (GM) as the average - like median, (and unlike arithmetic mean) it is not affected much by extreme values (e.g., GM of 8,27, and 125 is 30); unlike median, it incorporates the values of all observations in it. Further, appendix Table 1 gives their performance over the longest period for which we have comparable and reliable data. 
Next we examine the results of the natural experiment of joining EU. All four BHPR countries joined EU - Hungary and Poland in the middle of 2004, and Bulgaria and Romania on the first day of 2007. Panel $\mathrm{C}$ of Table 3 gives their catch-up to the EU accession year. Surprisingly, for 14 years of privatization/shift to a market economy, their economic performance was the same as during the command economy. That is, all the post-transition better economic performance came only after they joined EU. Privatization/mere shift to the market economy was not sufficient to boost growth; it required adopting EU norms and standards also.

Based on Solow (1957), comparative standards of living have been explained either in levels or in their growth. The former decomposes cross-section differences in output per worker levels into differences in physical capital-labor ratios, quality of human capital, and productivity. See, Caselli (2005) and Feenstra et al. (2015). The latter explains growth in output per worker by growth in the right hand side variables. The regressions are run for about 100 or more countries, and the results averaged across countries and across each decade. See, Jorgenson and Vu (2010).

Our interest is in explaining changes in the catch-up index and income ratios overtime. Let $k l$ represent physical capital per unit of employed labor, $h c$ average human capital (that is based on years of schooling and Mincerian returns to education), and $A$ the efficiency with which the factors are used, i.e., TFP. ${ }^{8}$ Letting per capita income approximate output per worker, ignoring the time sub-scripts, and using the neo-classical production function, e.g., as given in Caselli (2005), for Country J,

${ }^{8}$ PWT 9.0 and 8.0 call their human capital measure an "index." See, Feenstra et al. (2015), Inklaar and Timmer (2013) and PWT 9.0. We prefer the nomenclature "human capital measure" or "average human capital" since the values are not expressed as a ratio to a base year's values. 


$$
\mathrm{y}_{\mathrm{J}}=A_{\mathrm{J}} k l_{J}{ }^{\alpha} h c_{J}{ }^{1-\alpha}
$$

Then, Country J's income ratio to the US is,

$$
\left(\mathrm{y}_{\mathrm{J}} / \mathrm{yUS}\right)=\left(A_{\mathrm{J}} / A_{\mathrm{US}}\right)\left(k l_{J} / k l_{U S}\right)^{\alpha}\left(h c_{J} / h c_{U S}\right)^{1-\alpha}
$$

(4) tells us Country J's income ratio depends on ratios of the two TFPs, the two capitallabor ratios and the two average human capital. As noted above, Peron and Rey (2012), Cuberes and Jerzmanowski (2009), Jones and Olken (2008), and Fuchs-Schundeln (2008), use income relative to the US as the dependent variable. But do not take explanatory variables as relative to the corresponding US/a bench mark country's numbers in their econometric investigation.

We estimate (4) (rather than use the catch-up index on the left hand-side and express the right hand-side ratios as indices too). We also do not take three-year moving-average values thereby obtaining data for 1960/1970 and 2014 as well. The estimable version of (4) is:

$$
\left(\mathrm{yJ}_{\mathrm{J}} / \mathrm{yuS}_{\mathrm{t}}=\mu+\beta_{1}\left(A_{\mathrm{J}} / A_{\mathrm{US}}\right)_{\mathrm{t}}+\beta_{2}\left(k l_{J} / k l_{U S}\right)_{t}+\beta_{3}\left(h c_{J} / h c_{U S}\right)_{t}+\varepsilon_{\mathrm{t}}\right.
$$

We undertake panel estimation of (5); separately for 1960/1970 to 1991,1991 to 2014 , 1991 to EU accession, and EU accession to 2014. These data are available in PWT 9.0 for these periods for BHPR countries. We take annual data rather than that averaged over five or ten nonoverlapping years since the latter throws away too much information. See, Attanasio et al. (2000). In panel estimation, following Kennedy (2008), we first test the null that the intercepts are equal. If this null is accepted, pooled OLS estimation is used. If it is rejected, we apply the Hausman test to test if the random effects model is unbiased. If this null is not rejected, we used the random effects model; if this null is rejected, we use the fixed effects model.

Table 2 presents panel estimation results for income ratios for the two periods, and the second period's two sub-periods, for BHPR countries. The panels for each period is unbalanced. Based on the above considerations, all four panels are estimated by pooled OLS since they do not 
reject Breusch-Pagan Lagrange multiplier test of equal intercepts. All pooled OLS estimates are equal to the corresponding random-effect estimates. Surprisingly, TFP's contribution to catchingup is almost the same for the pre-transition and post-transition periods. Estrin et al. (2009) find the effect of privatization of state-owned enterprises on efficiency and TFP is mostly positive in Central Europe. We do not find privatization-boosted TFP contributed more to income in BHPR countries after privatization than it did before privatization. The only reason for boost to income growth in the post EU accession period is the almost double contribution of human capital. It more than makes up for the decline in the contribution of physical capital to income in the post-transition period.

Comparing the two sub-periods of the post-transition period, human capital is not significant in the first, and physical capital is significant at $10 \%$ level in the second. All other coefficients are significant at $1 \%$ level. Although the contribution of TFP declines, the said decline is more than made up by human capital in the post EU accession period - its contribution is almost four times what it was in the socialist and the 1991 to EU-accession periods (although the latter effect is not statistically significant). Human capital entirely explains the higher catchingup by BHPR countries in both the post-socialist and the post-EU-accession periods.

\section{3. "New" ex-socialist countries}

This section analyzes the catching-up experience and growth factors for ex-socialist entities that came into being or re-emerged as separate independent countries in 1991/1993 by i) the breakup of the former U.S.S.R. into its constituent republics, ii) the dissolution of the former Yugoslavia, and iii) the splitting of Czechoslovakia into its two parts; limiting ourselves to countries for which data on explanatory variables are available. We divide these countries into three groups based on the following ex ante and ex post factors: whether they aspired to EU membership and joined it in 
2000s, whether their separation accompanied internecine war for many years, and whether formed into CIS. The first group consists of Slovenia, the Baltic countries, the Czech Republic and Slovakia, called hereinafter as SBCS countries, who joined EU in the middle of 2004 (and were under the Soviet system for about five decades); the second of ex-Yugoslavia countries Croatia and Serbia, (and were under the Soviet system for about four decades); and the third group of exSoviet Union countries, Armenia, Kazakhstan, Kyrgyz Republic, Moldova, Russian Federation, Tajikistan and Ukraine, (and were under the Soviet system for about seven decades). ${ }^{9}$

Table 3A presents catching-up results for "new" ex-socialist countries in three panels: Panel I for SBCS countries; Panel II for Croatia and Serbia; and Panel III for CIS countries, The "new" ex-socialist countries have experienced significantly worse economic performance than "old" ex-socialist (BHPR) countries over the same period. The three groups of "new" ex-Socialist countries have caught-up/fallen-behind Germany (that grew at $2.5 \%$ ) at $0.61 \%, 0.58 \%$, and -2.19 $\%$ rate, respectively - versus $1.50 \%$ catching-up for the "old" socialist countries. Megginson (2005) found that mass privatization did not yield the expected positive results. We find the results varied greatly among the four groups of ex-socialist countries with them arranged in the following descending order: "old" ex-socialist (BHPR), SBCS, Croatia and Serbia, and CIS - even though all four groups had almost the same trajectory of privatization and transition to a market economy. See, Figure 3.

We also find that, in contrast to Svejnar (2002), i) Balkan and Baltic countries, Romania, Estonia, Lithuania, Latvia, and Bulgaria, on average have performed better than the Central European countries of Poland, Hungary, Slovakia, Slovenia, and the Czech Republic in the posttransition period (indicating that geography-related initial conditions have not held the former

\footnotetext{
${ }^{9}$ Due to its limited period under EU, we ignore Croatia joining EU in the middle of 2013.
} 
group back); and ii) Slovenia and the BHPR countries (other than Bulgaria) did not have a larger relative income gap with advanced economies like Germany in 2001 than at the start of the transition. $^{10}$

Figure 4 shows the dynamics of the average (GM) catch-up index for the four groups of ex-socialist countries for the 1991-2013 period. Roland (2000) finds no transition country avoided a serious and major output fall at the beginning of transition. We find the BHPR countries hardly show any falling-behind (Germany's growth). SBCS and Croatia and Serbia groups more than fully recover after an initial falling-behind. CIS countries fall-behind sharply for about ten years and their relative income was about 40\% lower in 2013 than what it was in 1991. Roland (2000) explains the initial fall to credit crunch, snapping of network externalities and freedom to engage in monopoly behavior by enterprises. Yet, he does not explain why these factors had no effect on BHPR countries and such strong effect in CIS countries (that their income gap from Germany is so much higher in 2013 than it was in 1991 - since relative divergence is sufficient for absolute divergence).

Figure 5 depicts the transition indicator (TI) for only the liberalization of trade and foreign exchange system for the four groups of ex-socialist countries - they are far closer to each other

\footnotetext{
${ }^{10}$ Similarly, Dell'Anno and Villa (2013) find positive growth rates over 1990-2009 for all ex-socialist countries except Kyrgyz Republic, Moldova, Serbia, Tajikistan and Ukraine. We find incomes of Moldova and Ukraine grew slightly, and of Serbia by about 3.3\% from 19912013. Vintrova (2009) finds that the Slovak income reached $84 \%$ of the Czech's by 2007 . We find the Slovak relative and absolute convergence with the Czech continued after 2007 too - by 2013, its income was 90\% of the Czech income.
} 
than the aggregate TI (shown in Figure 3). Yet, in contrast to the conclusions of Nannicini and Billmeier (2010) (that making the transition without opening up to trade considerably hampers growth) almost equal focus on external liberalization/opening up to trade did not benefit the four groups of countries equally whether in the short or the long-run.

On the other hand, Berkowitz and DeJong (2003) explain the enormous regional differences in economic growth rates in post-Soviet Russia by regional differences in price liberalization policies and large-scale privatization. Figure 6 depicts the average of price liberalization and large-scale privatization transition indicators for four groups of ex-socialist countries. The countries did not differ enormously by the extent of their price liberalization and large-scale privatization. Yet, they differed greatly in their growth and catching-up rates. What it suggests is that markets cannot be given a completely free-reign but countries/markets need to be "governed" by wise politicians and technocrats or constrained by proper institutions to ensure a positive outcome. See, Wade (1990).

Piatek et. al (2013) find causality from economic freedom to economic growth with one year lag using Heritage Foundation's index of economic freedom (IEE) for the former. They divide the post-socialist countries (25) in different groups, use IEE for 1995-2008, country fixed effects panel regression that uses a time trend instead of a constant, and lagged dependent variable on the RHS. We use EBRD's transition indicators (that are available since 1989) as indicators of privatization and the introduction of market economy and the next generation PWT 9.0 data (that goes up to 2014). We find the post-socialist performance is not uniformly positive. Assuming all ex-socialist countries in Europe were catching-up to Germany before 1991 at $0.90 \%$ annual rate, only BHPR countries show a slightly better post-socialist economic performance (at about onehalf point higher). Post-socialist SBCS countries and Croatia and Serbia catch-up to Germany at 
a lower rate, and CIS countries fall behind Germany, both relatively and absolutely.

Further, catching-up of SBCS countries happened only after they joined EU. Panel B of Table 3 shows these countries' incomes fell behind Germany's income for 13 years (1991 to 2004) since their launch of privatization and market economy. The shift to privatization and market economy increased income gaps of both SBCS and CIS countries from Germany. But, SBCS countries were able to stop their declining living standards vis a vis Germany after they joined EU. Both the i) higher catching-up of BHPR countries after privatization in 1991 (as compared to the period before that) and ii) all positive catching-up of SBCS countries since 1991, are entirely explained by the spurt in catching-up after they joined EU.

Now we study what changed in BHPR and SBCS countries in the few years before and after they joined EU. Bulgaria's accession was delayed because EU had especial concern about vast amount of corruption in high positions. The EU demanded Bulgaria needed to reestablish its legal codes; especially the system for prosecuting and investigating criminal networks, and enforcing laws surrounding money laundering and fraud. (Phinnemore, 2006). In January 2006, the Bulgarian legislature adopted reforms generated by the public-private initiative, Coalition 2000, in the areas of "political level corruption, VAT fraud, a stricter system of implementation monitoring and a stronger mandate for the oversight government commission and in limiting or lifting the immunity of members of parliament and magistrates under specified conditions." (Pond, 2006).

The issues on which Hungary had to satisfy the EU before accession included bringing its food processing and animal slaughter houses to EU's sanitary codes or animal health guidelines by the end of 2006; and its urban waste water treatment and collection systems to EU's standards by the end of 2004. (Gottfried, P. and P. Györkös, 2007). Requirements on Poland were similar; 
it also, at the EU's request, agreed to open its real estate market to the EU citizens. (Kułakowski, and Jesień, 2007). Romania had to increase legal force to deal with its corruption, consolidate judicial and police reform and tackle issues on human rights, freedom of the press, and minority protection before being allowed into the EU. (Phinnemore, 2006 and Lusman, 2014).

Like it did with Hungary, the EU persuaded Slovenia to bring its food processing and animal slaughter houses to EU's sanitary codes or animal health guidelines and its urban waste water treatment and collection systems to EU standards. (Potočnik, et al. 2007). Estonia had to agree to rely on other sources of power than the shale oil they had been using (environmental reform), satisfy EU of its hunting regulations, and revise many parts of its tax law, including its entire set of corporate income tax laws. (Streimann, 2007). Latvia agreed to limit licensing requirements to a narrower scale of business activities, to raise the savings guarantees in the national banks as well as to introduce an Investment Compensation System by 2008, and to restructure each one of its milk, meat, and fish processing facilities. (Kesteris and Plamse, 2007). Lithuania consented to the shutting down of its two nuclear reactors, the first by 2005 , and the second, by 2010, and to a closer enforcement of its borders with the Russian state of Kaliningrad. (Auštrevičius, 2007)

On the other hand, the Czech Republic agreed to adequately staff its state aid systems and closure of the majority of its banks by the European Commission that the EC had deemed corrupt. These banks were rebuilt using foreign involvement. (Telicka and Bartak, 2007). Slovakia had to change its whole political structure in 1999 - with its first-ever presidential elections in May 1999 - to even be considered by the EU as a candidate for negotiations. They also had to adopt new laws into their constitution to align it with the needs of the European Commission and the Council 
of Europe and to increase transparency of governmental decisions. It had to restructure its entire banking structure, and to tighten tax-discipline of its business sector. (Figel' and Adamiš, 2007).

Clearly, privatization, rapidly adopted in the early 1990s, was not sufficient for growth. It also needed legal, judicial and police reforms, restructuring of banking, adopting EU standards and practices in every detail, and increased transparency and control of political level corruption. Berkowitz, et al. (2014) find privatizing state-owned banks in Russia did not have any impact on economic growth if the banks still retained political connections. We find a stronger result: mass privatization across all industries in ten countries (BHPR and SBCS) did not boost growth if any of the problems listed in the previous paragraph were present.

Table 4 presents panel estimation results for growth factors "new" ex-socialist countries. Croatia and Serbia and CIS panels are strongly balanced; with 25 observations for each country. Croatia and Serbia panel is estimated by pooled OLS since it does not reject Breusch-Pagan Lagrange multiplier test of equal intercepts; as before, the pooled OLS estimates are equal to the corresponding random-effect estimates. The CIS countries panels reject Breusch-Pagan Lagrange multiplier test of equal intercepts as well as the Hausman test of unbiased random effects. It is estimated by the fixed effects model. Two panels for SBCS countries are used: one for the period from 1990 to EU accession, and the other from EU accession to 2014. The contribution of physical capital to growth is much smaller in the second period, and its level of significance drops from $1 \%$ to $10 \%$. On the other hand, human capital, that was not significant in the first period and had the negative sign, becomes significant at $1 \%$ level in the second period and has a strong positive effect. The only reason that explains catching-up of SBCS countries after they joined EU (as compared to the period before it) is human capital; the only reason that explains falling behind of the CIS countries is the negative contribution of human capital. On the other hand, only physical capital 
and TFP explain the catching-up of Crotia and Serbia since the coefficient on human capital is negative. TFP's contribution to catching-up is more than double in SBCS countries for the postEU period than it is in of Crotia and Serbia.

The above results may be contrasted to those by Dombi (2013). Read it again. He finds the main source of economic growth for ten Central Eastern European (CEE) post-socialist countries between 1995 and 2007 to be physical capital followed by TFP; and that of human capital to be marginal. We, on the other hand, do not find physical capital played an important role in SBCS countries in their post-EU period while the role of human capital there was strong. On the other hand, Prochniak (2011) finds human capital was a very important determinant of growth for 1993-2009 in the 10 Central and Eastern European (CEE) countries. ${ }^{11}$

Doucouliagos and Ulubasoglu (2006) and Calvo and Sanchez-Robles (2003) find privatization/market economy/economic freedom spur economic growth by boosting domestic and foreign investment. Our results generally support these conclusions. For each group of countries, the effect of physical capital on catching-up growth is positive, and is statistically significant in three out of four cases at $1 \%$ level. Nevertheless, for CIS countries, this positive effect is not successful in preventing their falling behind in the post-socialist period.

We have shown above that the contribution of human capital is the most important factor explaining both the i) higher catching-up of BHPR countries after privatization in 1991 (as compared to the period before that) and ii) all positive catching-up of SBCS countries since 1991 Now, we examine whether human capital had a similar role in growth/catching-up of pre-2004 EU

\footnotetext{
${ }^{11}$ Countries used by Prochniak (2011) are Bulgaria, Czech Republic, Estonia, Hungary,
} Latvia, Lithuania, Poland, Romania, Slovakia, and Slovenia. 
countries; i.e., countries that were EU members before its 2004 expansion.

Table 5 presents the catching-up to Germany since 1991 of pre-2004 EU countries. Of the three countries that had higher 3-year moving-average income than Germany in 1991, Denmark, Luxembourg and Sweden, two (Denmark and Sweden) fell behind Germany and so did more than half of the other countries. Although the GM of 14-countries' catching-up rate is slightly positive $(0.16 \%$, and $.02 \%$ without Ireland), if these countries are collectively considered as one country called, say, Western Europia, its absolute income gap from Germany widened over 1991-2013 since the more populous parts of Western Europia (France, Italy and U.K.) fell behind; and relative divergence is sufficient for absolute divergence. ${ }^{12}$

Table 6 reports results from panel estimation of growth factors of pre-2004 EU countries. For ease of comparison, it also reproduces the results for growth factors for BHPR and SBCS countries since their accession to EU. For all three groups of countries, TFP is not the most important factor; human capital is. The negative contribution of capital-intensity for pre-2004 EU countries is surprising. The capital measure is physical (tangible) capital. It is possible this measure understates total capital: Some capital may be intangible capital that is mistakenly included in human capital.

We also calculate and report in Tables 1 and 3 the time it will it take for ex-socialist countries to reach income equality with Germany, following Kant (2018). Based on the past catching-up for the longest period for which we have reliable and comparable data, Appendix Table 1 and Tables 1 and 3 project BHPR countries will reach income equality with Germany in

\footnotetext{
${ }^{12}$ Western Europia's income fell behind Germany's at the annual rate of $0.20 \%(0.23 \%$ excluding Ireland) during this period.
} 
107 years (but 72 years if the 1991-2013 catch-up rate is used); SBCS countries in 104 years, Croatia and Serbia in 193 years, and CIS countries have no prospect for ever reaching income equality with Germany. These results are to be taken with caution since the time for income quality with the benchmark country depends both on the period used for projecting into the future and the benchmark country considered. ${ }^{13}$ Although Kant (2018) finds that of the 28 countries in South Asia and Sub-Saharan Africa that caught-up to the US from 1992 to 2013, 21 fell behind over a longer period; and the longer period catching-up rate of most of them are one-fifth to about onehalf of the 1992-2013 rate; the European ex-socialist countries longer period performance could be better. On the other hand, Table 5 shows pre-2004 EU countries as a group may reach income equality with Germany in 70 years (529 years excluding Ireland); and Finland, Portugal, and Spain in 70,133, and 101 years, respectively. But, if these countries are considered one country, Western Europia, extending its 1991-2013 falling behind to the future means it has no prospect of ever reaching income equality with Germany.

\section{Conclusions}

We use two natural experiments to examine the growth effects of i) privatization/regime

${ }^{13}$ Comparing Appendix Table 1 to Table 1, BHPR countries' longer term catching-up is slower - over $1961 / 1971$ to 2013 , it is at $1.19 \%$ rate versus the $1.50 \%$ rate for $1991-2013$; and for two out of four countries the longer period catching-up rate is about one-third to two-thirds of the 1991-2013 rate. Further, all experienced no catching-up for periods ranging from 20 to 25 years. This happened even though all these countries are upper middle income (two) or high income (two) as compared to South Asian and Sub-Saharan African countries where virtually all are lower income or lower middle income. 
change from command to market economy and ii) joining EU using the ex-socialist countries in Europe. As far as I can tell, none of the empirical studies of this question have used data for both the post-1990 to the pre-1991 periods. We use the comparable pre-1991 data also; as well as using the longest post-1990 data that are available, and use the catch-up index and income ratio in our analysis. We group these countries into four: a) countries that have existed as separate countries since at least the Second World War, called BHPR (Bulgaria, Hungary, Poland, and Romania), or "old" ex-socialist countries, and three groups of "new" ex-socialist countries: b) Slovenia, Baltic, the Czech republic and Slovakia (SBCS) - who joined EU in 2014, c) Croatia and Serbia - that experienced civil war after the break-up of Yugoslavia, and d) ex-Soviet Union countries that formed into CIS.

Estrin et al. (2009)'s conclude centrally planned economies had poor economic performance in the pre-transition, and were expected to vastly improve it post-transition; and privatization mostly affected TFP positively, implying the enhanced TFP boosted growth. Our analysis shows BHPR countries were catching up to Germany at $0.90 \%$ rate in the centrally planned period. In the privatized and market economy period, the catching up increased by about 0.5 points (to $1.50 \%$ ); but the better performance entirely occurred only after these countries joined EU about 14 years later. Similarly, SBCS countries income gap with Germany was wider in 2004 than it was in 1991 and they caught up only after joining EU; while CIS countries fell-behind so sharply that they still are at about 60\% of the relative income to Germany level they had in 1991. Privatization and shift to a market economy itself widened the income gap of most of these countries from Germany, but countries that joined EU were able to stop the relative divergence 
from the year of accession. ${ }^{14}$

In contrast to Estrin et al. (2009), we find TFP's contribution to output for BHPR countries was almost the same in the post-transition and pre-transition periods. Considering only the posttransition period, the "new" ex-socialist countries have done worse than "old" ex-socialist countries and reforms did not impose any short run costs on BHPR countries. All four groups of ex-socialist countries had almost the same trajectory of privatization and overall transition to a market economy. Contrary to Nannicini and Billmeier (2010) and Berkowitz and DeJong (2003), the greatly different growth/catching-up in short/long term cannot be explained by differing emphasis on external or price liberalization or privatization.

Panel estimation shows that human capital entirely explains the post-transition higher catching-up of BHPR countries and falling-behind of CIS countries. While TFP is behind the growth/catching-up of both, in post-EU SBCS countries the additional factor is human capital while in Croatia and Serbia it is physical capital. These results are different from those by Dombi (2013), and Prochniak (2011). Human capital, not TFP, is the dominant factor for faster catch-up, or any catch-up, of all three groups of countries: BHPR and SBCS countries since their accession to EU, and pre-2004 EU countries.

We also examine within group convergence and years for full convergence to Germany. Dispersion of absolute incomes has decreased in i) BHPR, ii) SBCS, and iii) Croatia and Serbia, has almost doubled in CIS countries; and has trebled for all these countries as a group from 19912013. Based on catching-up/falling-behind based on the 1991-2013 performance, CIS countries

\footnotetext{
${ }^{14}$ As a point of comparison, we note that more than half of the "old" EU countries also fell behind Germany from 1991 to 2013.
} 
have no prospect of ever equaling German income, pre-2004 EU countries will reach income equality with Germany in 70 years, BHPR countries in 72 years; SBCS countries in 104 years, and Croatia and Serbia in 193 years.

We now note some of the implications of this paper and suggestions for further research. The weaker growth effects of transition in "new" ex-socialist countries might be due to the burden of governance as a sovereign country for the first time and undertaking regime change while grappling simultaneously with costs and burdens of separate statehood. Standard scale effects (increasing returns in the provision of public goods and non-rivalrous technology) raise the administrative costs both in the main unit in the former united country/empire (e.g., Russia in the U.S.S.R. and Serbia in Yugoslavia) as well as in the new units that are spun off.

Second, de jure privatization and introduction of a market economy is not de facto introduction in view of ingrained habits and customs of people. Fuchs-Schundeln and Hassan (2015) identify three aspects of fundamental causes of growth: institutions, social structure, and culture. Even if institutions change, old social structure, and culture may persist. For example, Alesina and Fuchs-Schundeln (2007) and Okulicz-Kozaryn (2014) find that after 45 years under communism, ex-socialist countries' residents were favorably disposed to redistribution by the state (and, if anything, increased their preference for redistribution) and were not ready for unbridled privatization, market economy and competition.

Third, political integration does not mean economic integration. Nitsch and Wolf (2009) find that although administrative barriers to trade between East and West Germany were rapidly eliminated with the fall of the Berlin Wall, the intra-German trade pattern has persisted along the former East-West border. The persistence of old trade patterns and economic relationships among CIS countries is likely to be even greater. 
Lastly, even though its growth effects may be mixed, as noted by Shleifer and Vishny (1994), massive privatization may have been necessary to root out the command economic system based on communist ideology. It may also have been necessary to root out tentacles of the communist party reaching almost all sections of the society, and to eliminate the fear of the secret police, arbitrary detention and may be execution. But, giving free reins to animal spirits of capitalism is no guarantee of honest new production and innovation. Animal spirits can also be used as freedom for predation, diversion, and rent accumulation. Prevention of diversion and pocketing of gains from investments and technology by bureaucrats, politicians, insiders, controlled shareholders, and lawyers/judges is essential. 


\section{References}

Acemoglu, D. (2009). Introduction to Modern Economic Growth. Princeton University Press.

Acemoglu, D., Johnson, S., and Robinson, J.A.. 2005. Institutions as the Fundamental Cause of Long-Run Economic Growth. In: Agion, P., Durlauf, S. (Eds.), Handbook of Economic Growth. North Holland, Amsterdam, pp. 385-472.

Alesina, A. and N. Fuchs-Schundeln (2007). Good Bye Lenin (or Not?): The Effect of Communism on People. American Economic Review 97 (4), 1507\{1528.

Attanasio, O. P., L. Picci, and A.E. Scorcu (2000. Saving, growth, and investment: A Macroeconomic Analysis using a panel of countries. Review of Economics and Statistics 82, 182211.

Auštrevičius, P. (2007), “The Accession of Lithuania to the EU," in G. Vasileiou, (ed.) The Accession Story: The EU From 15 to 25 Countries. Oxford: OUP Oxford

Babecky, J. and T. Havranek (2014). Structural Reforms and Growth in Transition: A Meta-analysis. Economics of Transition, 22(1), 2014, pp. 13-42.

Calvo, M.B. and Sanchez-Robles, B., 2003. Foreign direct investment, economic freedom and growth: new evidence from Latin-America. European journal of political economy, 19 (3), $529-545$.

Cieslik, A. and Tarsalewska, M., (2013), "Privatization, Convergence, and Growth: Evidence for Transition Economies.” Eastern European Economics, 51(1), January-February 2013, pp. 5-20.

Bennett, J., S. Estrin, and G. Urga, 2007. Methods of Privatization and Economic Growth in Transition Economies. Economics of Transition, 15(4): 661-83. 
Berkowitz, D., Hoekstra, M., and Schoors, K., (2014), "Bank Privatization, Finance, and Growth.” Journal of Development Economics, 110(0), September 2014, pp. 93-106.

Berkowitz, D., and DeJong, D. N. 2003. Policy Reform and Growth in Post-Soviet Russia. European Economic Review, 47(2): 337-52.

Caselli, F. (2005). Accounting for cross---country income differences in Phillipe, A. and S. N. Durlauf (eds.) Handbook of Economic Growth, Volume 1A, Elsevier: 679---741.

Cuberes, D. and M. Jerzmanowski (2009). 'Democracy, Diversification and Growth Reversals', Economic Journal, 119(540), 1270-1302.

Dell'Anno, R. and S. Villa (2013), “Growth in Transition Countries, Big Bang versus Gradualism.” Economics of Transition, Vol. 23, No. 3, pp. 381-417.

Djankov, S. and Murrell, P., (2002), "Enterprise Restructuring in Transition: A Quantitative Survey.” Journal of Economic Literature Vol. XL (September 2002) pp. 739-792

Doucouliagos, C. and Ulubasoglu, M.A., 2006. Economic freedom and economic growth: does specification make a difference? European journal of political economy, 22 (1), 60-81.

Dombi, A., 2013. The Sources of Economic Growth and Relative Backwardness in the Central Eastern European Countries between 1995 and 2007. Post-Communist Economies 25(4), $425-47$.

Eicher, T.S. and Schreiber, T., 2010. Structural Policies and Growth: Time Series Evidence from a Natural Experiment. Journal of Development Economics, 91(1), 169-79.

Estrin, S., J. Hanousek, E. Kocenda, and J. Svejnar (2009). The Effects of Privatization and Ownership in Transition Economies. Journal of Economic Literature, 47(3), September 2009, $699-728$. 
European Bank for Reconstruction and Development. Transition Reports 1998-2007, London: European Bank for Reconstruction and Development and available at http://www.ebrd.com/downloads/research/economics/macrodata/tic.xls

Feenstra, R.C., R. Inklaar, and M.P. Timmer (2015). 'The Next Generation of the Penn World Table,' American Economic Review, 105(10), 3150-82.

Figel,' J. and Adamiš, M., (2007), “The Accession of Hungary to the EU," in G. Vasileiou, (ed.) The Accession Story: The EU From 15 to 25 Countries. Oxford: OUP Oxford

Fuchs-Schundeln, N. (2008). The Response of Household Saving to the Large Shock of German Reunification. American Economic Review 98 (5), 1798-1828.

Fuchs-Schundeln, N. and T. Hassan (2015). Natural Experiments in Macroeconomics. C.E.P.R. Discussion Papers, CEPR Discussion Papers: 10628, 2015 and NBER Working Papers: 21228.

Gottfried, P. and P. Györkös, 2007, "The Accession of Hungary to the EU," in G. Vasileiou, (ed.) The Accession Story: The EU From 15 to 25 Countries. Oxford: OUP Oxford

Gouret, F., 2007. Privatization and Output Behavior during the Transition: Methods Matter! Journal of Comparative Economics, 35(1): 3-34.

Guiso, L., P. Sapeinza, and L. Zingales (2011). Civic Capital as the Missing Link, Chapter in Civic Capital as the Missing Link, pp. 417\{480. Elsevier.

Gylfason, T., 1998. Privatization, Efficiency and Economic Growth. Centre for Economic Policy Research Discussion Paper 1844.

Hansen, C.W., and Longstrup, L. 2015. The Rise in Life Expectancy and Economic Growth in the 20th Century. Economic Journal, 125(584), 838-52. 
Hansen, N.A., 1997. Privatization, Technology Choice and Aggregate Outcomes. Journal of Public Economics, 64(3): 425-42.

Heritage Foundation, Index of economic freedom. Methodology, [online]. Available from: http://www.heritage.org/index/book/methodology,

Inklaar, R. and D.S. P. Rao (2017). 'Cross-Country Income Levels Over Time: Did The Developing World Suddenly Become Much Richer?', American Economic Journal: Macroeconomics, 9(1), 265-90.

Inklaar, R. and M.P. Timmer (2013). Capital, labor and TFP in PWT 8.0. Groningen Growth and Development Centre, University of Groningen.

Jorgenson, D. W. and K. M. Vu (2010). Potential Growth of the World Economy. Journal of Policy Modeling 32(5): 615---631.

Jones, B.F., and A. Olken (2008). 'The Anatomy of Start-Stop Growth', Review of Economics and Statistics, 90(3), 582-587.

Jones, C., and Romer, P.M., 2012. New Kaldor Facts: Ideas, Institutions, Population, and Human Capital. American Economic Journal: Macroeconomics 2, 224-245.

Kant, C., 2016. "Are Institutions in Developing Countries Malleable," Journal of Policy Modeling 38(2), 272-289.

Kant, C., 2018. Income Convergence and the Catch-Up Index. Forthcoming in North American Journal of Economics and Finance. Published online August 16, 2018, doi.org/10.1016/j.najef.2018.07.017

Kaufmann, D., Kraay, A., and Zoido-Lobatón, P., (1999a and 1999b). “Aggregating Governance Indicators;” and “Governance Matters.” World Bank Policy Research Working Paper Nos. 2195 and 2196, Washington, D.C. 
Kaufmann, D., Kraay, A., and Mastruzzi, M. 2004. Governance Matters III: Governance Indicators for 1996, 1998, 2000, and 2002. World Bank Economic Review, Vol. 18, Issue 2, pp. 253-87.

Kennedy, P. (2008). A guide to econometrics, $6^{\text {th }}$ Ed., Blackwell.

Kesteris, A. and K. Plamse, "The Accession of Latvia to the EU" in G. Vasileiou, (ed.) The Accession Story: The EU From 15 to 25 Countries. Oxford: OUP Oxford

Kułakowski, J. and L. Jesien (2007), "The Accession of Poland to the EU” in G. Vasileiou, (ed.) The Accession Story: The EU From 15 to 25 Countries. Oxford: OUP Oxford

Lusman, I., (2014), "European Union Accession Conditionality and Human Rights in Romania," in Children's Rights, Eastern Enlargement and the EU Human Rights Regime, Manchester; New York: Manchester University Press

Megginson, William L. 2005. The Financial Economics of Privatization. Oxford and New York: Oxford University Press

Nannicini, T. and Billmeier, A., 2011. Economies in Transition: How Important Is Trade Openness for Growth? Oxford Bulletin of Economics and Statistics 73(3), 287-314.

Nitsch, V. and Wolf, N., 2009. Tear Down this Wall : On the Persistence of Borders in Trade. University of Warwick, Department of Economics, The Warwick Economics Research Paper Series (TWERPS).

North, D.C., 1990. Institutions, Institutional Change, and Economic Performance. Cambridge University Press, Cambridge.

Nunn, N., 2014. "Historical Development" in Handbook of Economic Growth, Vol. 2A, Eds. S. Durlauf and P. Aghion. Amsterdam: Elsevier B.V. 
Okulicz-Kozaryn, A. (2014). Winners and Losers in Transition: Preferences for Redistribution and Nostalgia for Communism in Eastern Europe. Kyklos 67(3), 447-61. Peron,O. and S. Rey (2012). 'Trade and Convergence of Per Capita Income in the Indian Ocean Zone, 1950-2008', Annals of Regional Science, 49, 657-683.

Phinnemore, D. (2006). "Two More for the Club." The World Today, Vol. 62, no. 10, pp. 22-23.

Piatek, D., K. Szarzec, and M. Pilc, (2013). Economic Freedom, Democracy and Economic Growth: A Causal Investigation in Transition Countries. Post-Communist Economies, 25(3), September 2013, 267-88.

Pond, E. (2006), "Endgame in the Balkans: Regime Change, European Style" (Ch. 2, Reinventing Bulgaria, pp. 39-67). Brookings Institution Press

Prochniak, M., 2011. Determinants of Economic Growth in Central and Eastern Europe: The Global Crisis Perspective. Post-Communist Economies 23(4), 449-68.

Potočnik, J., F. Černe, E. Erjavec and M. Mrak, "The Accession of Slovenia to the EU" in G. Vasileiou, (ed.) The Accession Story: The EU From 15 to 25 Countries. Oxford: OUP Oxford PWT 9.0 (2015), Human capital in PWT 9.0.

Rodrik, D., (Ed.), 2003. In Search of Prosperity: Analytic Narratives on Economic Growth. Princeton University Press, Princeton, N.J.

Roland, G. (2000). Transition and Economics: Politics, Markets and Firms. Cambridge, MA: MIT Press.

Shleifer, A. and R.W. Vishny, 1994. Politicians and Firms. Quarterly Journal of Economics, 109(4): 995-1025. 
Solow, R. M. (1956). A contribution to the theory of economic growth. The Quarterly Journal of Economics 70 (1), 65-94.

Streimann, A., (2007), "The Accession of Estonia to the EU" in G. Vasileiou, (ed.) The Accession Story: The EU From 15 to 25 Countries. Oxford: OUP Oxford

Svejnar, J., 2002. Transition Economies: Performance and Challenges. Journal of Economic Perspectives 16(1), 3-28.

Swan, T. W. (1956). Economic growth and capital accumulation. Economic Record 32 (2), $334-361$.

Telicka, P. and Bartak, K. (2007), "The Accession of the Czech Republic to the EU, in G. Vasileiou, (ed.) The Accession Story: The EU From 15 to 25 Countries. Oxford: OUP Oxford Vintrova, R., 2009. Lessons from the Czech and Slovak Economies Split. Prague Economic Papers 18(1), 3-25

Wade, R., 1990. Governing the Market. Princeton: Princeton University Press.

World Bank, 2014. 2011 International Comparison Program. World Bank. Washington, D.C.

World Bank, 2013. Measuring the Real Size of the World Economy: The Framework, Methodology, and Results of the International Comparison Program (ICP). World Bank. Washington, D.C.

World Bank. World Development Indicators. World Bank. Washington, D.C. 


\section{Table 1: Catch-up of BHPR countries}

A) 1961/1971 to 1991

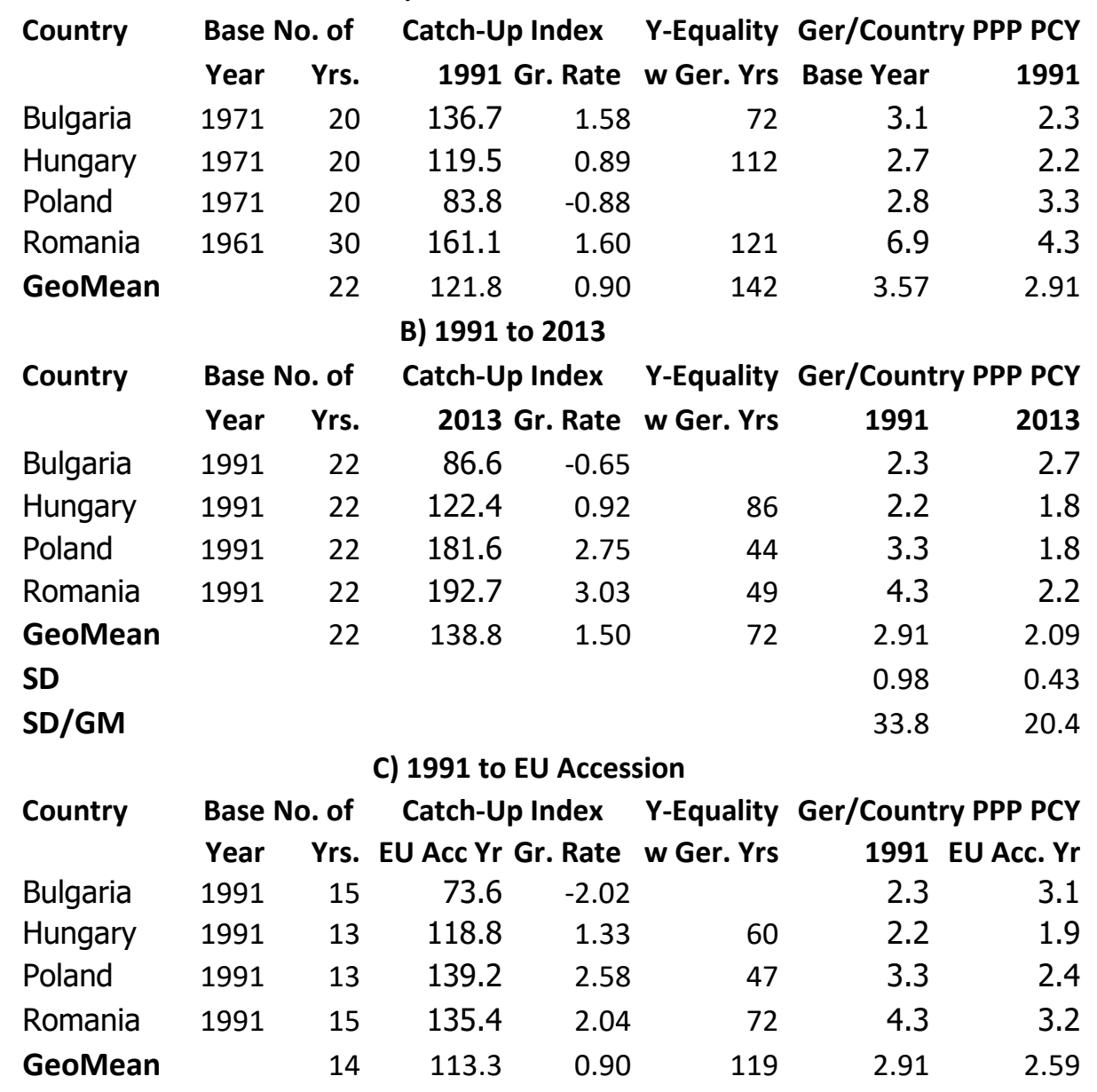

Notes: BHPR stands for Bulgaria, Hungary, Poland, and Romania. Data from which the above resu are derived is from PWT 9.0. See, Kant (2018) for the equation to derive years for full convergenc Bulgaria and Romania joined EU on January 1, 2007 while Hungary and Poland did so on May 1, 2 
Table 2: Growth factors for BHPR countries

1960/1970-1991 1991 to EU Acc. EU Acc. To 2014

$\begin{array}{lccr}\text { K/L ratio } & \begin{array}{c}0.7288^{*} \\ (0.0387)\end{array} & \begin{array}{c}0.2777^{*} \\ (0.0151)\end{array} & 0.1939 * * * \\ & & & (0.1181) \\ \text { Human capital } & 0.5520^{*} & 0.4446 & 1.8350^{*} \\ & (0.1088) & (0.2775) & (0.4411) \\ & & & \\ \text { TFP } & 0.3143^{*} & 0.6706^{*} & 0.1934^{*} \\ & (0.0148) & (0.0302) & (0.0680)\end{array}$

$\begin{array}{llll}\text { No. of obs. } & 98 & 60 & 38\end{array}$

Panel Unbalanced Unbalanced Unbalanced

Estimation method Random effects Random effects Random effects

or pooled OLS or pooled OLS or pooled OLS

$\begin{array}{llll}\text { Adj. R-sq } & 0.9336 & 0.9418 & 0.8430\end{array}$

$\begin{array}{llll}\text { R-sq } & 0.9356 & 0.9448 & 0.8734\end{array}$

Notes: See above. The numbers in parenthesis are the standard errors of the

estimated coefficients in the row directly above. ${ }^{*}$ and $* * *$ indicate significance at $1 \%$ and $10 \%$

levels, respectively. The estimation results with pooled OLS are identical to using randm effects

GLS model. BHPR stands for Bulgaria, Hungry, Poland, and Romania, respectively. 
Table 3A: Catch-up to Germany of new or reemergent independent countries Country Catch-Up Index Y-Equality Ger./Country PPP PCY 2013 Gr. Rate w Ger. Yrs $1991 \quad 2013$

$\begin{array}{lr}\text { Czech Republic } & 94.3 \\ \text { Estonia } & 148.9 \\ \text { Latvia } & 97.5 \\ \text { Lithuania } & 137.1 \\ \text { Slovakia } & 115.5 \\ \text { Slovenia } & 102.8 \\ \text { GeoMean } & 114.3 \\ \text { SD } & \\ \text { SD/GM } & \\ & \\ \text { Croatia } & \\ \text { Serbia } & 108.6 \\ \text { GeoMean } & 118.6 \\ \text { SD } & 113.5 \\ \text { SD/GM } & \end{array}$

\section{I) SBCS countries}

$\begin{array}{rrrr}-0.27 & & 1.4 & 1.5 \\ 1.83 & 48 & 2.4 & 1.6 \\ -0.12 & & 1.9 & 2.0 \\ 1.45 & 58 & 2.3 & 1.7 \\ 0.66 & 98 & 1.9 & 1.6 \\ 0.12 & 378 & 1.6 & 1.5 \\ 0.61 & 104 & 1.88 & 1.88 \\ & & 0.39 & 0.22 \\ & & 20.5 & 11.5\end{array}$

II) Croatia and Serbia

$\begin{array}{rrrr}0.37 & 223 & 2.3 & 2.1 \\ 0.78 & 179 & 4.0 & 3.4 \\ 0.58 & 193 & 3.03 & 2.67 \\ & & 1.20 & 0.92 \\ & & 39.6 & 34.4\end{array}$

III) CIS countries

$\begin{array}{lrrrrr}\text { Armenia } & 105.9 & 0.26 & 657 & 5.6 & 5.3 \\ \text { Kazakhstan } & 121.7 & 0.90 & 98 & 2.4 & 2.0 \\ \text { Kyrgyz Republic } & 28.8 & -5.50 & & 3.9 & 13.6 \\ \text { Moldova } & 62.0 & -2.15 & & 6.0 & 9.7 \\ \text { Russian Federation } & 75.6 & -1.26 & & 1.4 & 1.9 \\ \text { Tajikistan } & 30.3 & -5.28 & & 4.9 & 16.3 \\ \text { Ukraine } & 62.6 & -2.11 & & 2.7 & 4.2 \\ \text { GeoMean } & 61.4 & -2.19 & & 3.45 & 5.64 \\ \text { SD } & & & 1.74 & 5.73 \\ \text { SD/GM } & & & 50.5 & 101.5\end{array}$

3B: Catch-up to Germany for SBCS countries from 1991 to EU Accession Country Catch-Up Index Y-Equality Ger./Country PPP PCY 2004 Gr. Rate w Ger. Yrs $1991 \quad 2004$

$\begin{array}{lrrcrr}\text { Czech Republic } & 92.6 & -0.59 & & 1.4 & 1.5 \\ \text { Estonia } & 112.4 & 0.90 & 97 & 2.4 & 2.1 \\ \text { Latvia } & 77.0 & -1.99 & & 1.9 & 2.5 \\ \text { Lithuania } & 100.9 & 0.07 & 1260 & 2.3 & 2.3 \\ \text { Slovakia } & 91.6 & -0.67 & & 1.9 & 2.0 \\ \text { Slovenia } & 112.5 & 0.91 & 52 & 1.6 & 1.4 \\ \text { GeoMean } & 97.0 & -0.23 & & 1.88 & 1.92\end{array}$

Notes: See above. The base year for all countries is 1991 and the number of years is 22 for all pane except $3 \mathrm{~B}$ where it is 13 years. 
Table 4: Growth factors for "new" ex-socialist countries

SBCS

Crotia \& Serbia

CIS

1990 to EU Acc. EU Acc. To 2014

K/L Ratio

$0.3792 *$

$0.0618 * * *$

(0.0560)

(0.0362)

$0.8276^{*}$

$0.1932 *$

Human Capital

$-0.1016$

$0.8362 *$

(.2010)

(.0428)

(0.1335)

(0.2748)

$-1.6813^{*}$

$-.1211$

(0.0916)

TFP

$$
\begin{gathered}
0.7523^{*} \\
(0.0397)
\end{gathered}
$$

$0.7845^{*}$

(0.5012)

$0.3282 *$

$0.4436 *$

(0.0839)

(0.0154)

No. of obs.

90

66

50

175

Method

Random effects

Random effects Pooled OLS or RE

Fixed effects

R-sq

0.8506 (between) 0.3859 (between)

0.76980 .8420 (within)

Adj. R-sq

NA

NA

0.7547

NA

Notes: See above. SBCS panels are unbalanced, the other two panels are stongly balanced. SBCS stands for Slovenia, Baltic countries, the Czech Republic, and Slovakia. 
Table 5: 2013 Catch-up to Germany for pre-2004 EU countries

\begin{tabular}{|c|c|c|c|c|c|}
\hline \multirow[t]{2}{*}{ Country } & \multicolumn{2}{|c|}{ Catch-Up Index } & Y-Equality & \multicolumn{2}{|c|}{ Ger./Country PPP PCY } \\
\hline & 2013 & Gr. Rate & w Ger. Yrs & 1991 & 2013 \\
\hline Austria & 107.7 & 0.34 & NA & 1.019 & 0.946 \\
\hline Belgium & 98.4 & -0.07 & & 1.013 & 1.029 \\
\hline Denmark & 99.3 & -0.03 & & 0.998 & 1.005 \\
\hline Finland & 104.4 & 0.19 & 70 & 1.145 & 1.098 \\
\hline France & 92.0 & -0.38 & & 1.058 & 1.149 \\
\hline Greece & 89.3 & -0.52 & & 1.541 & 1.726 \\
\hline Ireland & 154.9 & 2.01 & NA & 1.471 & 0.949 \\
\hline Italy & 82.9 & -0.85 & & 1.029 & 1.241 \\
\hline Luxembourg & 121.3 & 0.88 & NA & 0.585 & 0.482 \\
\hline Netherlands & 105.0 & 0.22 & NA & 1.001 & 0.953 \\
\hline Portugal & 109.9 & 0.43 & 133 & 1.769 & 1.610 \\
\hline Spain & 108.6 & 0.38 & 101 & 1.461 & 1.345 \\
\hline Sweden & 96.9 & -0.14 & & 0.977 & 1.008 \\
\hline UK & 95.4 & -0.21 & & 1.094 & 1.146 \\
\hline GM & 103.53 & 0.16 & 70 & 1.12 & 1.08 \\
\hline SD & & & & 0.30 & 0.30 \\
\hline $\mathrm{SD} / \mathrm{GM}$ & & & & 27.1 & 28.2 \\
\hline \multicolumn{6}{|c|}{ Excluding Ireland } \\
\hline GM & 100.37 & 0.02 & 529 & 1.094 & 1.089 \\
\hline SD & & & & 0.301 & 0.312 \\
\hline SD/GM & & & & 27.5 & 28.7 \\
\hline
\end{tabular}

Notes: See above. The base year for all countries is 1991 and the number of years is 22 . 
Table 6: Growth factors for "new" and "old" EU countries

Panel Estimation

BHPR SBCS "Old" EU countries

EU Acc. To 2014 EU Acc. To 2014 1990-2014

K/L Ratio

$0.1939 * * *$

$0.0618 * * *$

$-0.1299 *$

(0.1181)

(0.0362)

(0.0355)

Human Capital

1.8350*

$0.8362 *$

2.7588*

(0.4411)

(0.2748)

(0.2943)

TFP

$\begin{array}{lll}0.1934^{*} & 0.7845^{*} & 0.3900^{*} \\ (0.0680) & (0.1137) & (0.0582)\end{array}$

No. of obs.

38

66

350

Estimation Method

Random effects Random effects

Fixed effects

$\mathrm{R}-\mathrm{sq}$

0.84300 .3859 (between)

0.2094 (within)

Adj. R-sq

0.8734

NA

NA

Notes: See above. BHPR and SBCS panels are unbalanced while "old" EU panel is stongly balanced. BHPR stands for Bulgaria, Hungry, Poland, and Romania, respectively, SBCS stands for Slovenia, Baltic countries, the Czech Republic, and Slovakia and "old EU" for pre-2004 members of EU. 
Figure 1: PCY Index 1961-2013, BHPR \& Germany

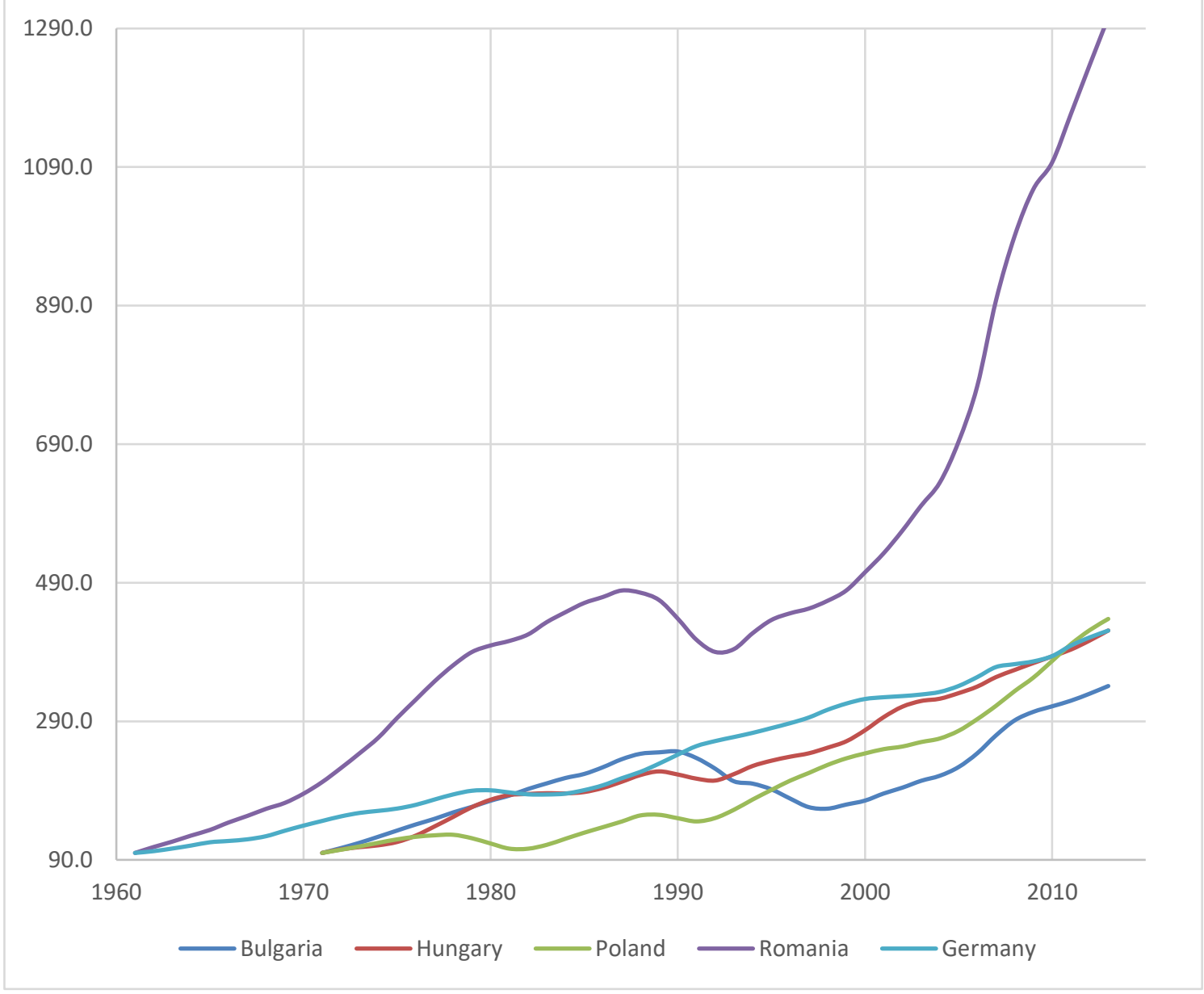


Figure 2: Catch-up Index 1961-2013, BHPR

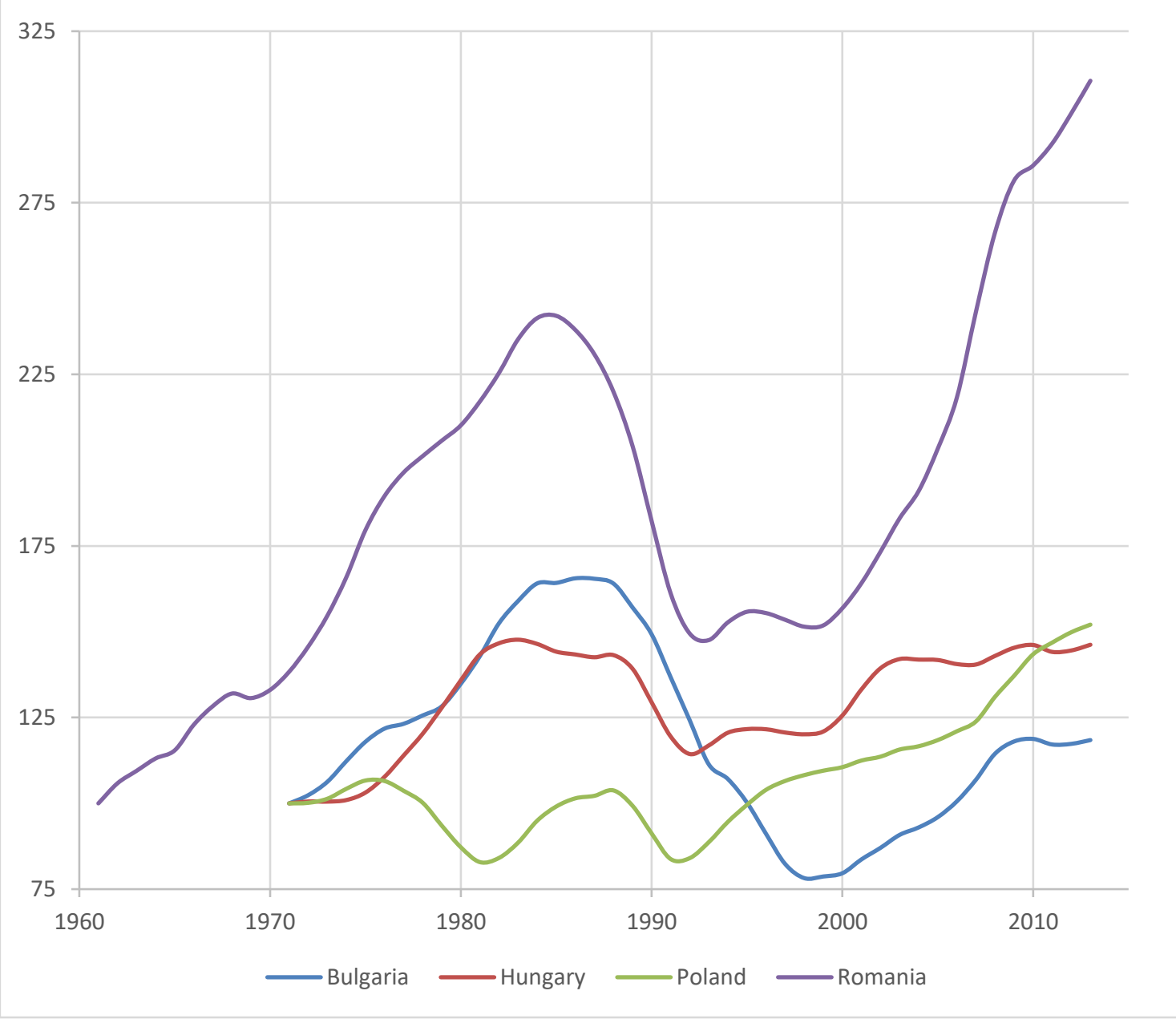


Figure 3: Transition Indicators 1990-2013;

Four Groups of Ex-Socialist Countries

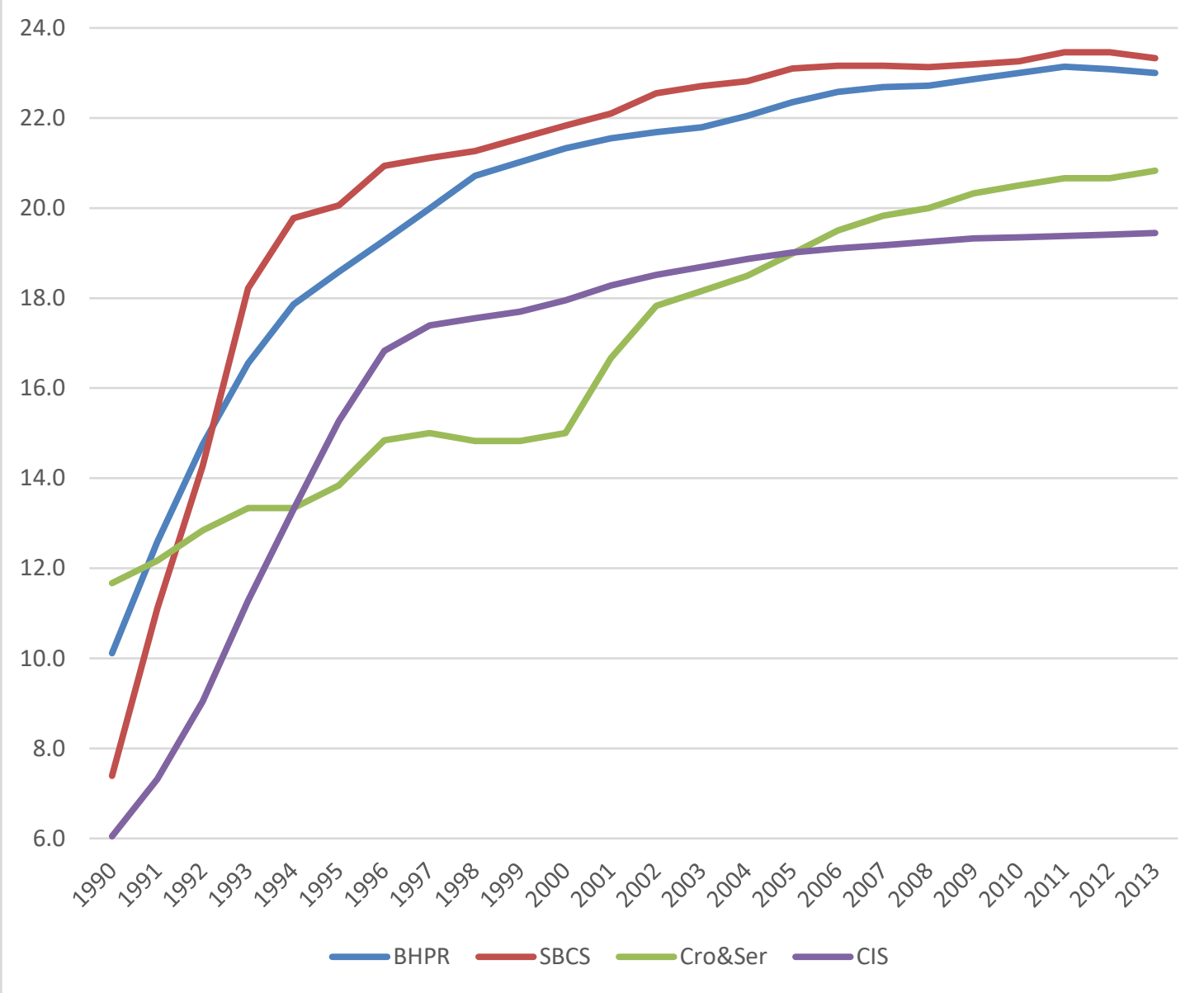




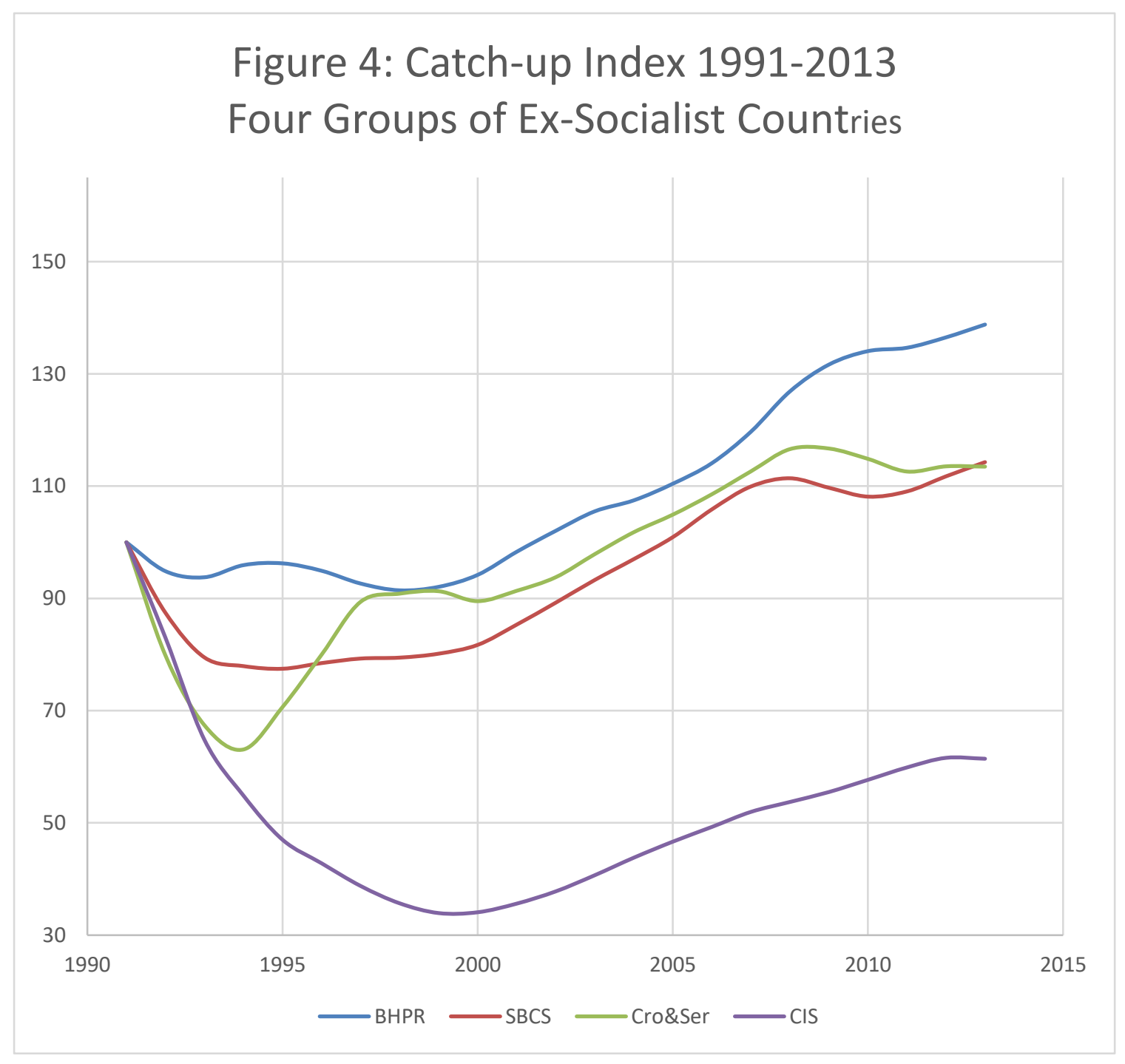


Figure 5: External Transition Indicators 19902013; Four Groups of Ex-Socialist Countries

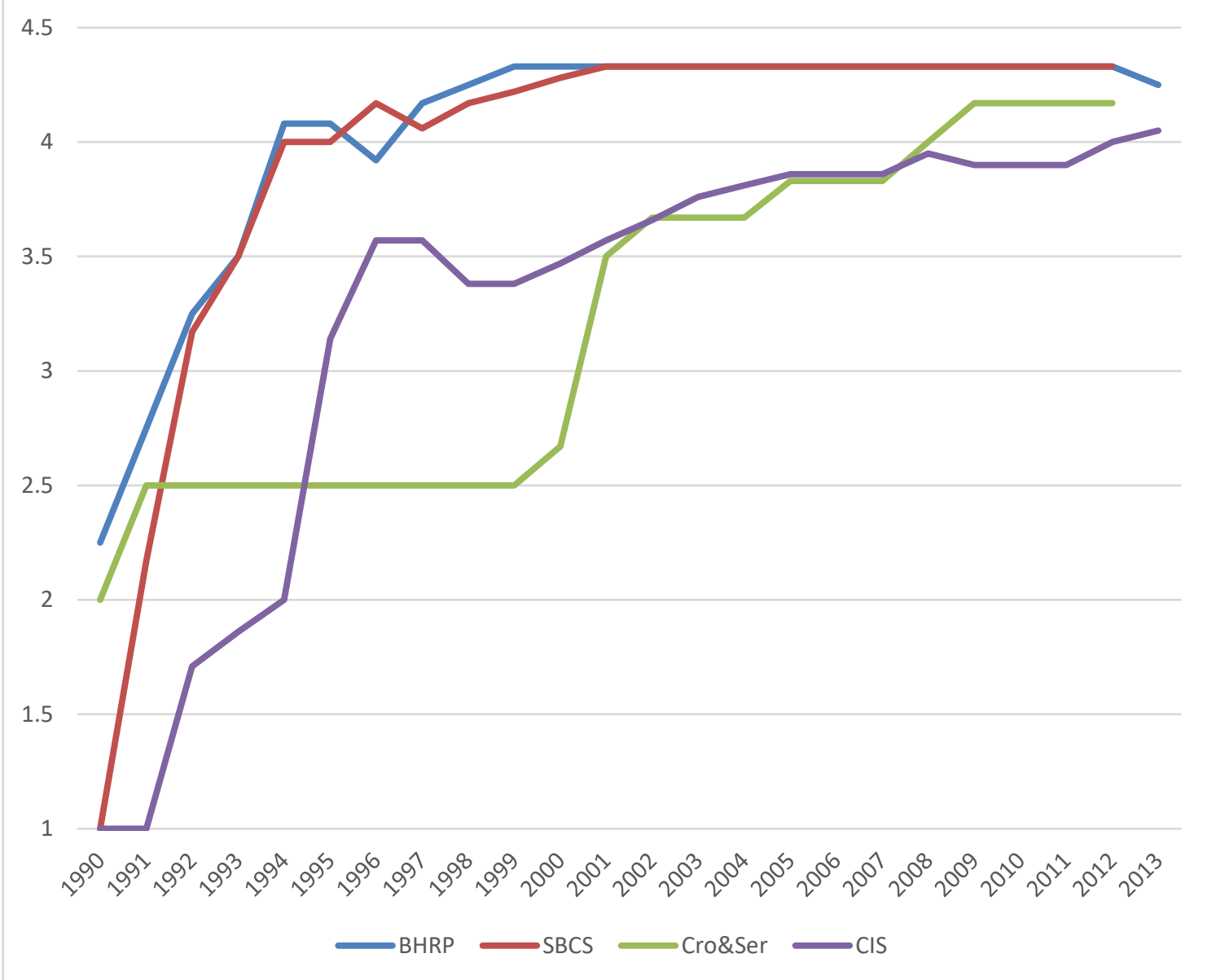


Figure 6: LS Privatization \& Price Lib. TIs 19902013; Four Groups of Ex-Socialist Countries

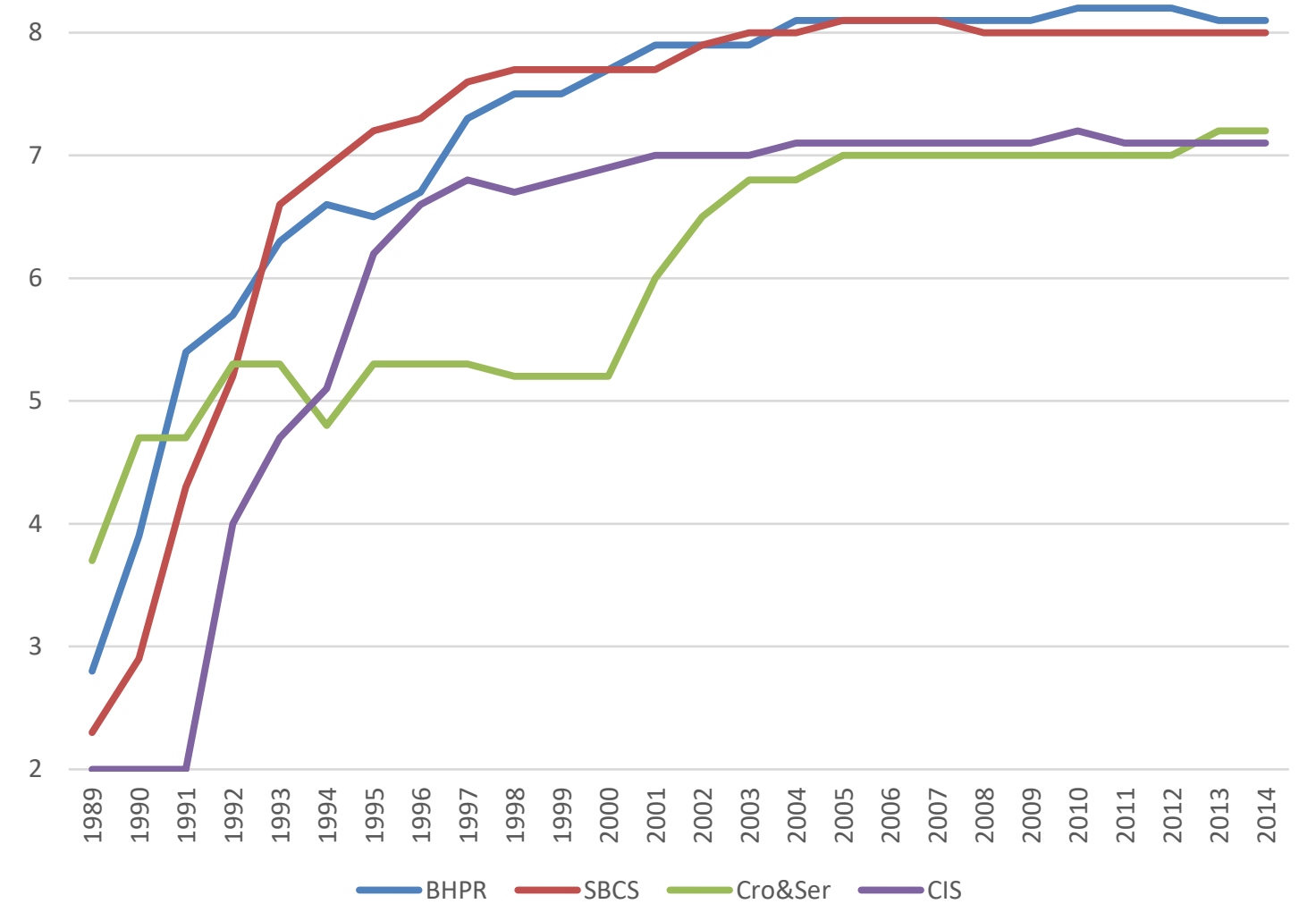

